Dragana Rogić,

UDK: 904:75.052"652"(497.11)

Archaeological Institute, Belgrade

ID: 195908108

rogic.dragana@gmail.com

Maja Gajić-Kvaščev,

University of Belgrade, Vinca Institute of Nuclear

Sciences, Belgrade

Original research article

Velibor Andrić,

University of Belgrade, Vinca Institute of Nuclear

Sciences, Belgrade

\title{
ANALYSIS OF BLUE AND GREEN PIGMENTS FROM THE FRESCO PAINTED TOMBS OF VIMINACIUM
}

\begin{abstract}
Blue and green pigments from fresco painted tombs of Viminacium were analysed using nondestructive EDXRF spectrometry. Based on the results gained, it can be concluded that within this Late Antique palette of green colour, there were copper based pigments: malachite, verdigris or chrysocolla and green earth, while the blue pigments included Egyptian blue and azurite.
\end{abstract}

KEY WORDS: EDXRF, PIGMENT, GREEN, BLUE, WALL PAINTINGS, LATE ANTIQUE.

\section{INTRODUCTION}

The wall paintings of Viminacium represent very precious finds. In the territory of Serbia, there are, altogether, nine wall painted painted tombs from the Late Antiquity, among which five were discovered in Kostolac-Viminacium (M. Korać 2007: 15). ${ }^{1}$ The tombs were discovered in the period from 1983 to 1990 , during archaeological excavations. The analysed frescos are very

1 At Viminacium, 28 fresco painted tombs were discovered, among which only five were well-preserved, while the others were not preserved at all. Those paintings are fragmented and devastated due to robberies during Antiquity and in modern times (M. Korać 2007: 15). well preserved and belong to the period from the beginning to the second half of the $4^{\text {th }}$ century. Late Antique tombs, as well as earlier tombs, were decorated because a tomb represented a home in the after-life (Rogić, Anđelković 2012: 85). However, there is a difference in the decoration of tombs. Given the quality of the paintings from the tombs discussed in this paper, it can be concluded that they were very luxurious.

This paper deals with the analyses of blue and green pigments used for depicting images on tomb walls in Viminacium. Four tombs, marked as G-5517, G-2624, G-3130 and G-5464, were chosen for analysis. Unfortunately, fresco pig-

* The article results from the projects: IRS - Viminacium, Roman city and military legion camp - research of material and non material culture of inhabitants by using the modern technologies of remote detection, geophysics, GIS, digitalisation and 3D visualisation (no 47018), and ON177012 and TR37021 funded by Ministry of Education, Science and Technological Development of the Republic of Serbia. 
ments from the tomb G-160 were not analysed due to technical reasons. The paintings were made using the fresco technique. ${ }^{2}$ Among the colours used for painting, one can see: blue, green, white, red, ochre, brown and black along with mixtures of these colours.

\section{DESCRIPTION OF TOMB PAINTINGS}

The tomb G-5517 (site Pećine) is known as the "Tomb with Christ's monogram". It was discovered in 1990, during archaeological excavations ${ }^{3}$ and dated to the first half of the $4^{\text {th }}$ century. ${ }^{4}$ The frescoes were very well preserved, removed and conserved.

The painted decoration covers the entire interior of the tomb. 5 The Christ's monogram within a laurel wreath is the motif depicted on the western, front side. Under the monogram, at a point $0.62 \mathrm{~m}$ above the floor, there is a brick placed as a small shelf. On the eastern, front wall, there is a picture of two peacocks with a cantharos between them and floral motifs behind them. On

2 Fresco technique is a process of painting on a wet mortar surface. The mortar is made of water slaked lime and an aggregate filling. The binding material for painting is lime water containing dissolved calcium-hydrate. Colour fixing is achieved through a chemical reaction resulting in the formation of a transparent film of calcium carbonate on the surface of the painting. Pigments resistant to the alkaline surrounding were used, mostly natural pigments (earth, mineral), but also some artificial ones (for example Egyptian blue).

3 The grave construction consisted of bricks and filling and was of a trapezoidal cross-section. Its base width measures $1.70 \mathrm{~m}$ and the width at the top is $0.90 \mathrm{~m}$. The grave is paved with bricks. The preserved outer grave dimensions are $2.92 \times 2.20 \times 1.69 \mathrm{~m}$, while the preserved inner dimensions measure $2.10 \times 1.95 \mathrm{~m}$.

4 Constantinvs.

5 On the floor of the grave there were remains of the deceased with grave-goods. The bones were dislocated and fragmented due to robbery, while four skulls remained - three fragmented and one complete. The long bones were also fragmented. At the upper grave level there was a bronze coin - C 13280 (Constantine). At a point 0.30 $\mathrm{m}$ above the floor there was another coin - C 13281 (S. Severus). Among the bones there was a glass flask. the northern and southern sides there are hunting scenes. Above all of the scenes mentioned, there is a frieze of vines. The colours used are: blue, red, ochre, black, white and various nuances of these colours (Fig. 1).

The tomb G-2624 (site Pećine) was excavated in 1983, during archaeological excavations ${ }^{6}$ and dated to the first half of the $4^{\text {th }}$ century. ${ }^{7}$ All four sides were decorated with frescos. The frescos were well-preserved, removed and conserved.

The inner tomb surface is covered with two layers of mortar. The first layer is lime mortar, 0.5 to $3 \mathrm{~cm}$ thick, used to straighten the tomb walls. Over this layer, there is a mortar layer on which the painting was performed (1 to $1.5 \mathrm{~cm}$ thick). The portrait of a young woman is depicted on the western frontal side, while on the eastern one there is a standing male figure. On the lateral sides there are peacocks facing the young woman (Fig. 2).

The tomb G-3130 (site Skladište mazuta) was discovered in 1983, during archaeological excavations $^{8}$ and dated to the second half of the $4^{\text {th }}$

6 The grave was constructed from bricks. It was covered with bricks placed in the shape of a gable-roof, while under this construction, there were horizontally placed bricks $(60 \times 60 \times 8 \mathrm{~cm})$. The tomb was made out of 17 rows of bricks bound with lime mortar. The floor was also paved with bricks. Those placed in the western part were sloped, making a sort of a pillow, which was also covered with mortar. The tomb is of trapezoidal cross-section. The floor dimensions are $2.55 \times 1.15 \mathrm{~m}$, the dimensions of the opening are $2.55 \times 0.47 \mathrm{~m}$. The inner tomb height is $1.20 \mathrm{~m}$. It is orientated W-E, with a deviation of $2^{\circ}$ of its western part towards the north. Two fragments of a light grey pottery vessel glazed with olive-green glaze and three fragments of non-glazed pottery were discovered within the tomb. The tomb was robbed in Antiquity. Two persons were buried in it, their bones being dislocated.

7 Constantinvs II.

8 The tomb was made of bricks bound with lime mortar and has a rectangular base. The outer dimensions are 260 x $205 \times 80 \mathrm{~cm}$, the inner ones $200 \times 150 \times 80 \mathrm{~cm}$ and the depth is $75.08 \mathrm{~cm}$. The floor was paved with bricks but is not preserved. The floor substructure consisted of a $2 \mathrm{~cm}$ thick sand layer. The walls are $30 \mathrm{~cm}$ thick. At the preserved upper wall level there are the visible beginnings of wedge-shaped fugues, indicating a barrel vault. It is orientated W-E, with a $12^{\circ}$ deviation of its western part towards the south. The skeleton was not preserved. The 

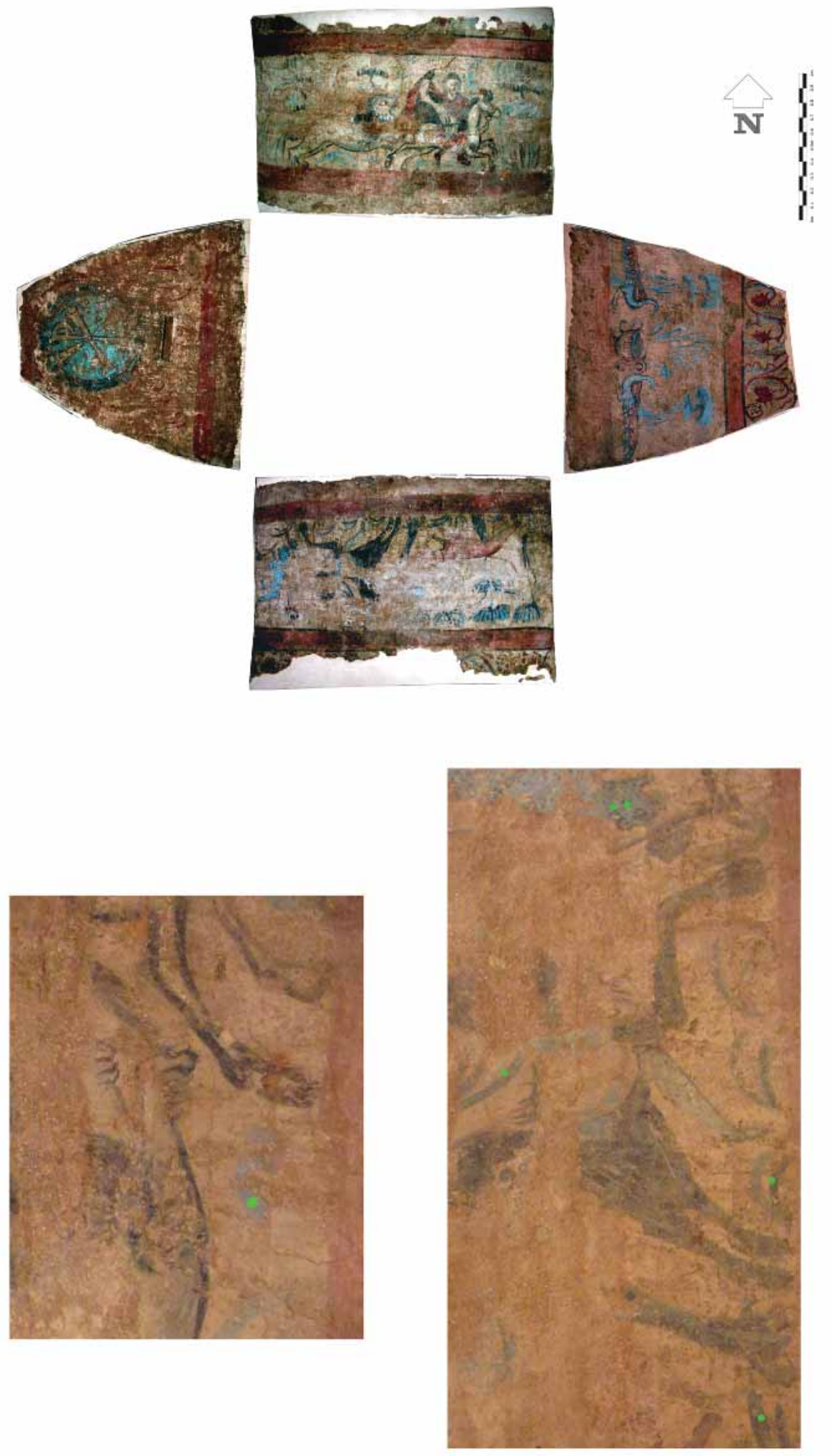

Fig. 1. Wall paintings from the tomb G-5517 with marked places of analysis. 

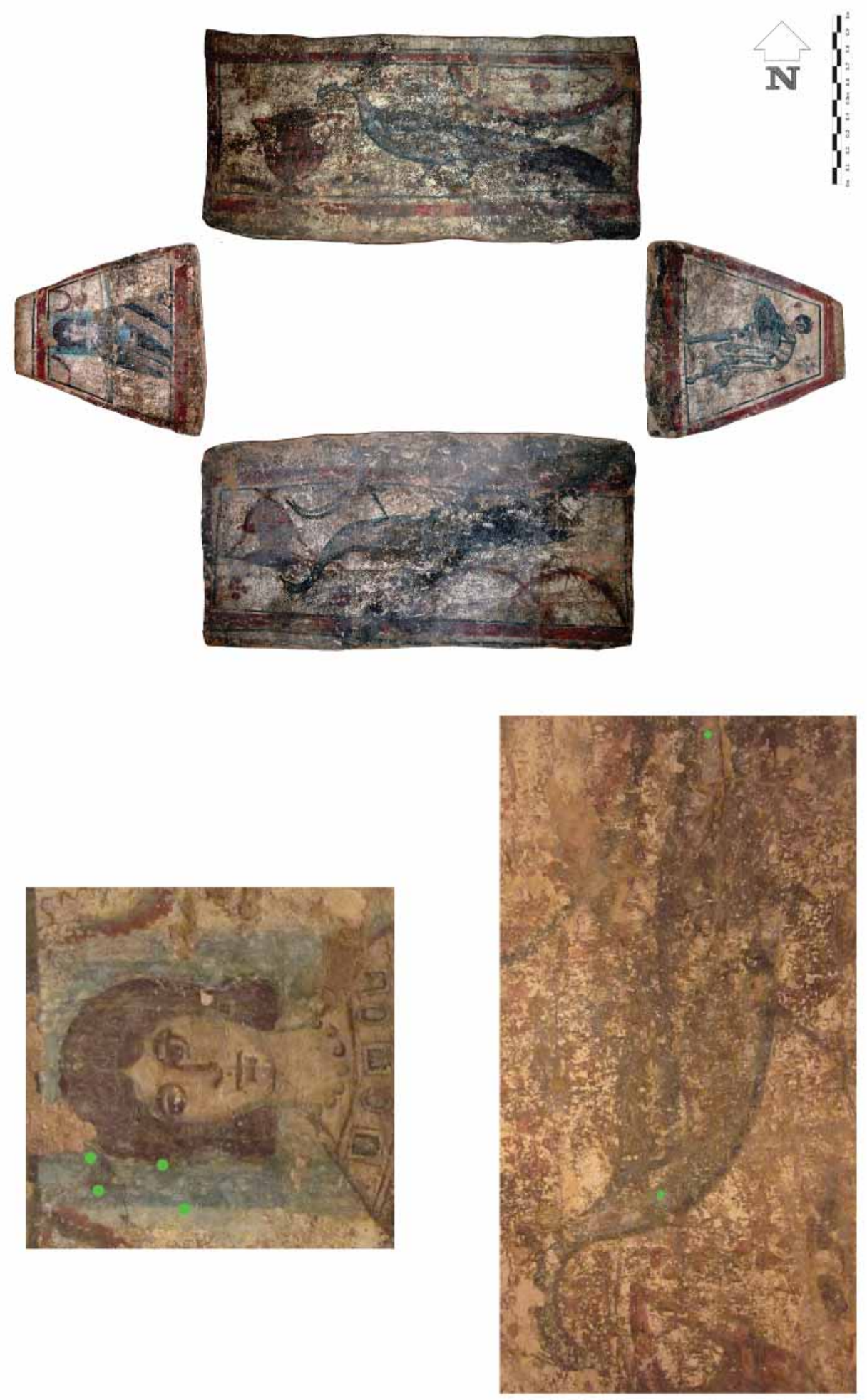

Fig. 2. Wall paintings from the tomb G-2624 with marked places of analysis. 



Fig. 3. Wall paintings from the tomb G-3130 with marked places of analysis. 

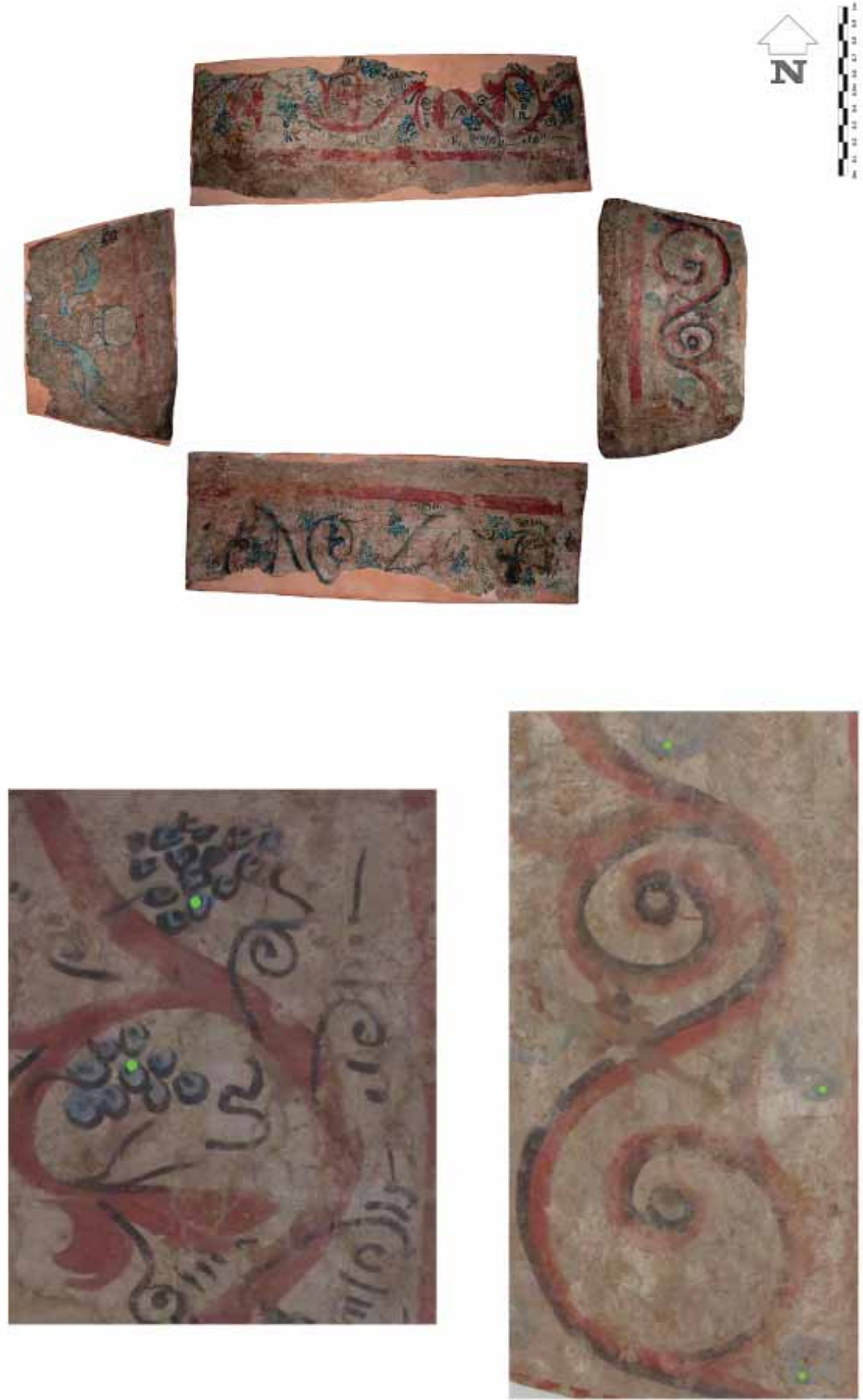

Fig. 4. Wall paintings from the tomb G-5464 with marked places of analysis. 
century. The frescos remained preserved only in the lower tomb zone and were removed and conserved.

The inner tomb surface is covered with two layers of mortar. The first layer is lime mortar with fine sand, $2 \mathrm{~cm}$ thick. The second layer (on which painting was performed) contains a higher percentage of ground brick and is 1 to 1.5 $\mathrm{cm}$ thick. The western lateral side contains an imitation of marble within rectangular fields, while on the eastern side, a detail of bird's feet remain preserved. Among the colours, there are greenishblue, red, black and ochre (Fig. 3).

The tomb G-5464 (site Pećine) was discovered in 1988, during archaeological excavations ${ }^{9}$ and dated to the second half of the $4^{\text {th }}$ century. ${ }^{10}$ The cover and the upper wall level were destroyed. The frescos have been removed and the lower parts of the compositions are conserved.

On the western side, there are two peacocks, painted facing each other with a spherical amphora between them. The peacocks were depicted using a light blue colour, while the contours of their bodies were depicted with a dark brown colour. The contours of the white amphora were also made using dark brown. One of the peacocks (the one to the north) is bent over the vessel, while the other one (the one to the south) is lifting its head. The whole image is framed with a red edge. On the eastern wall there is a spiral linear motif painted red and blue. On the longitudinal sides there are spirally depicted vines with leaves and grapes. The dominant colours are blue, red, white and black (Fig. 4).

tomb was mostly destroyed during a robbery and there were no grave goods.

9 The tomb was built of bricks bound with mud. It possesses a rectangular base and a trapezoidal cross-section. The floor is paved with bricks, and in the western part bricks are placed in such a manner that they form a socalled pillow. The outer tomb dimensions are $2.80 \times 2.00$ x $0.90 \mathrm{~m}$ and the inner dimensions (floor) 2.20 x $0.60 \mathrm{~m}$. The dimensions of the opening are $2.20 \times 1.25 \mathrm{~m}$ and the depth is $1.15 \mathrm{~m}$.

10 Iovianus.

\section{BLUE AND GREEN PIGMENTS OF THE ANTIQUITY}

Pigments can be divided into several groups: natural and mineral pigments, synthetic in-organic pigments, natural organic pigments, synthetic organic pigments and metals. Blue and green pigments used in the Antiquity belong to natural mineral pigments, synthetic inorganic pigments and natural organic pigments, while those analysed in this paper belong to two groups: natural mineral pigments and synthetic inorganic pigments.

Natural mineral pigments are oxides, sulphides, carbonates and metal sulphates which can be found in earth. In ancient times, pigments were obtained through grinding, flotation, sedimentation, refining and drying in the sun. The purity and quality of pigments depended on the depositing and drying process (Pathak 2003: 5). During calcination, heating at high temperatures, crystalline water is lost, admixtures are removed and the coverage is increased. Often, earth pigments possess higher grain and a better resistance to climatic conditions. They belong to the oldest types of pigments.

Also belonging to the group of natural mineral pigments are: green earth, azurite, chrisocolla, malachite and lapis lazuli. These are all discussed in this paper.

Synthetic inorganic pigments are created by a chemical reaction as a deposit with specific colouring features and they mostly cannot be dissolved in water. They are manufactured using filtering, drying and grinding (Punda, Culic 2009: 45). This group includes Egyptian blue, which is a silicate of calcium and copper, followed by smalt (its composition being potassium glass coloured with cobalt oxide) and verdigris.

Natural organic pigments are obtained from animal or plant organisms, by depositing the colour independently or through a reaction. Among the pigments discussed in this paper, in- 


\begin{tabular}{|c|c|c|}
\hline \multicolumn{3}{|l|}{ Green colour } \\
\hline Pigment & Colour & Chemical formula \\
\hline Malachite & & $\mathrm{Cu}_{2} \mathrm{CO}_{3} \mathrm{Cu}(\mathrm{OH})_{2}$ \\
\hline Green earth & & $\mathrm{K}\left[\left(\mathrm{Al}, \mathrm{Fe}^{\mathrm{II}}\right),\left(\mathrm{Fe}^{\mathrm{II}}, \mathrm{Mg}\right]\left(\mathrm{AlSi}_{3}, \mathrm{Si}_{4}\right) \mathrm{O}_{10}(\mathrm{OH})_{2}\right.$ \\
\hline Verdigris & & $\mathrm{Cu}(\mathrm{OH})_{2}\left(\mathrm{CH}_{3} \mathrm{COO}\right)_{2} 5 \mathrm{H}_{2} \mathrm{O}$ \\
\hline \multicolumn{3}{|c|}{ Greenish - blue colour } \\
\hline Chrysocolla & & $\mathrm{CuSiO}_{3} \cdot \mathrm{nH}_{2} \mathrm{O}+\mathrm{Cu}_{2} \mathrm{CO}_{3}(\mathrm{OH})^{2}+\mathrm{CuCO}_{3}(\mathrm{OH})^{2}$ \\
\hline \multicolumn{3}{|l|}{ Blue colour } \\
\hline Azurite & & $2 \mathrm{CuCO}_{3} \mathrm{Cu}(\mathrm{OH})_{2}$ \\
\hline Egyptian blue & & $\mathrm{CaCuSi}_{4} \mathrm{O}_{10}$ \\
\hline Smalt & & $(\mathrm{Co}(\mathrm{SiO} 2) \mathrm{n})$ \\
\hline Lapis lazuli & & $\mathrm{Na}_{8}\left[\mathrm{SO}_{4} \mid\left(\mathrm{AlSiO}_{4}\right)_{6}\right]$ \\
\hline Indigo & & $\mathrm{C}_{16} \mathrm{H}_{10} \mathrm{~N}_{2} \mathrm{O}_{2}$ \\
\hline
\end{tabular}

Table 1. Green and blue pigments used in Antiquity.

digo belongs to this group.

In the prehistoric cave paintings of Altamira in Spain or Lasco in France, only green pigments were used, while in Egypt and during Antiquity, blue pigments obtained from ores were used (Berke 2009: 16). The first two inorganic pigments were produced in Egypt - lead white and Egyptian blue. In table 1 the features of green and blue pigments are shown, for which there is proof that they were used during Antiquity.

\section{GREEN PIGMENTS}

\section{Malachite}

Malachite $^{11}$ is a natural mineral (semiprecious stone), based on copper carbonate. It belongs to the group of natural inorganic pigments (Metka 1991: 315), with average transparency, of bluish green colour and has low stability. It was used from Antiquity until Baroque times.

Pliny referred to malachite as chrysocolla (a name used in modern times for a hydrated copper silicate). He mentions that malachite ores were obtained in Spain, Cyprus, Armenia and Macedonia. There was also a very cheap colour - Apianum which was actually false malachite, made of green earth and valued at one sestertius per pound (Pliny: XXXV. XXIX).

11 Names from the literature: verdigris, Spanish green lat. viridie hispanicum, Greek green - lat. Viridie graecum. 
Malachite was excavated in the eneolithic copper mine "Mali šturac" (Rudnik mountain, Serbia), but other copper mines are also known to have existed: Rudna Glava in eastern Serbia (during the period of the Vinča culture), Jaramovac by Priboj (during the period of the younger Vinča culture) (Antonović, Vukadinović 2012: 95-97). In modern times, copper deposits in Serbia have been found in Bor, Majdanpek, Krivelj, Cerovo, Valjevo, Rudnik, Belo Brdo, Trepča, Kosovska Mitrovica and Čadinje.

\section{Chrysocolla}

Vitruvius writes that chrysocolla was imported from copper mines in Macedonia (Vitruvius: VII. IX). Chrysocolla is a hydrated mineral of copper silicate, its mineral admixtures being quartz, azurite, malachite, cuprites and others. Depending on the admixtures, it can be blue or green, sometimes even black. Teophrastus and Pliny wrote about the mineral of chrysocolla, but there is a possibility that they mistook chrysocolla for other copper minerals like malachite.

When chrysocolla was used as pigment, the colour varied from green to turquoise blue. This pigment was found on the wall paintings in the tombs of the $12^{\text {th }}$ dynasty in El Bersha and in Kahun-u in Egypt (Scott 2002: 253). The name derives from the Greek words chrysos-gold and kolla glue, since it was used for soldering gold (Scott 2002: 253).

\section{Green earth (Terre Verte)}

It belongs to the group of pigments with natural inorganic origins. These are clays with large quantities of the green mineral glauconite ${ }^{12}$ and celadonite ${ }^{13}$ as well as hydro silicates $\mathrm{Fe}, \mathrm{Mg}$, $\mathrm{Al}, \mathrm{K}$ (Aliatis et all, 532). It can be of different nuances, ranging from very dark greenish-grey, olive-green, grey, blue and green to yellowish-

12 Glauconite is encountered in sandy forms of surface sediment rocks.

13 It was found pure in split metamorphic rocks, Aliatis et all, 532. Celadonite was called "Verona earth". green. This pigment is very resistant to light and chemicals and it partly reacts with acids and bases. When burnt, this pigment becomes greener and better at covering. It is a non-toxic pigment.

Green earth was used in Egyptian, Greek and Roman times and in later periods. Deposits of green earth were found in the modern Czech Republic, Italy, France, the Baltic countries, $\mathrm{Cy}$ prus, Poland, Hungary, England, Germany and others. In Roman times, the name "green earth" was given to creta viridis or apianum (Aliatis et all, 532) ${ }^{14}$, and was a pigment found in Italy (Verona), Spain and in Cyprus.

\section{Verdigris - Green of Greece}

Average bluish-green colour of low stability, it is a copper acetate composition and it was used ever since Antiquity, ${ }^{15}$ throughout the Middle Ages, Renaissance and Baroque. It was obtained through the reaction of vinegar with copper (Kajtez 2011: 5). With ageing, it turns dark brown or black. ${ }^{16}$

Pliny wrote about the frequent use of this pigment and its production. It was produced in vine-growing areas, since vinegar is a product related to wine production. Vinegar was poured over copper plates; the copper reacts forming a bluishgreen scum which is scratched off to produce a pigment. There is also a recipe in which copper is exposed to evaporate of fermented grapes. It is stated that at that time verdigris was often falsified. The way to check if it had been replaced with marble, pumice or rubber was to chew it, since these replacements grate under ones teeth. It could also be discovered by the use of the black paint used for painting leather (shoemaker's black). The test was performed with a red-hot shovel and if verdigris was mixed with shoemaker's black, it would become red. Forgeries can also be discov-

14 The name derives from a place in the Appiano valley (Verona); Aliatis et all, 532.

15 Mentioned by Theophrastus, Dioscorides and Pliny.

16 http://www.webexhibits.org/pigments/indiv/overview/ verdigris.html 
ered by soaking papyrus with cecidia solution, because when it is covered with verdigirs, it becomes black, but it can also be detected with the naked eye, as it possesses an "evil" green colour.

\section{BLUE PIGMENTS}

\section{Azurite}

Azurite is an azure blue copper mineral, formed from surface changes to copper. It possesses an azure blue colour and its name derives from the Persian word lazhward. It is prepared by grinding, washing and sieving. Rough ground azurite has a darker colour, while the finer ground variety possesses lighter tones. In nature, it often appears together with malachite, which is a green colour and derives from further changes to azurite (Mattei et all. 2008: 302). The process of azurite degradation turns it from blue to green, i.e. to malachite. Another form of azurite degradation is that which occurs in an alkaline surrounding or by heating whereby it turns into black copper oxide, i.e. tenorite (Mattei et all. 2008: 302). Freshly formed azurite is dark blue and over time it becomes lighter, until it changes its colour to green and becomes malachite. It was identified in Egyptian, Greek and Roman paintings, as well as in later periods.

According to Pliny, azurite from Armenia was sold at the price of 300 sestertii per pound (Pliny: XXXV. XXVIII). During the first centuries of the New Era, in the modern town of Wallerfangen in Saarland (Germany), there was a Roman mine in which the copper mineral azurite was obtained, becoming Egyptian blue following further processes. This pigment was traded in an area of several hundred square kilometres around the mine (Körlin 2010: 174).

\section{Egyptian blue}

Egyptian blue is one of the oldest synthetic pigments, used during the early Egyptian dynas- ties and until the end of the Roman era (Mazzocchin at all 2004: 129). The Romans called it caeruleum (Vitruvius). Rarely, this pigment was also used in Mesopotamia and Persia, in the Asyrian palace Til Barship, dated from $1000-612$ BC, as well as on Persian reliefs from the $6^{\text {th }}$ and $5^{\text {th }}$ century BC (Scott 2002: 358). Egyptian blue was widely used in the Mediterranean and in the area of the Middle East, due to trade and the spread of the production technology.

The preparation of blue colours was first performed in Alexandria. The procedure is as follows: sand with nitrate blooms is sieved until it becomes like flour, it is further soaked and small balls are kneaded by hand which are then dried. After drying, they are put into pottery vessels and then into an oven. Once the copper and sand are red-hot, they amalgamate, turning into steel-blue (Vitruvius VII. XI).

Egyptian blue pigment was made when a mixture of quartz sand, calcium carbonate, copper (azurite or malahite) and small amounts of alcalia were heated to a temperature of between 800 and $900^{\circ} \mathrm{C}$ for several hours, resulting in the first synthetic pigment. Nuances of this colour are different, depending on the production procedure and the amount of grein, which is added during grinding. Nuances range from dark blue to pale blue, as well as greenish or greyish nuances. Greenish nuances of this pigment derive from wollastonite. Such a pigment is called Egyptian green and was discovered in Nephertiti's tomb (Scott, 2002: 263).

Egyptain blue is a completely stable pigment on all media and in all materials. Even under strong light the colour does not change. The chemical formula for this pigment is actually cuprorivaite. Chemical analyses of samples from Antiquity differ in their composition quite a lot from pure cuprorivaite. The difference is caused by the presence of certain amounts of quartz and other phases of sillitium dioxide, such as pigmented tridymite, which did not react with the copper during the production procedure. Wollastonite can 
be present as a result of using lager amounts of lime in the initial material, while copper oxides, like cuprite or tenorite, can be formed if large amounts of copper are used. Still, cuprorivaite is a mineral which is very rare in nature and cannot be collected in quantities big enough to be used as a pigment. In the end, it was concluded that it is a natural parallel to cuprorivaite (Scott 2002: 259). From the discussion, we were able to conclude that nuances of Egyptian blue were quite different, while Berke explicitly mentions fabricing of this colour (Berke 2009: 17).

For Egyptians, blue represented the colour of the sky, the realm of gods and the colour of rivers, which represented floods and rich yields. Egyptian blue was used in combination with Lapis Lazuli for painting eyes, hair and the royal insignia, as well as other details in Egyptian paintings. The Egyptians considered blue as the colour of the universe and, therefore, temple ceilings were painted blue.

Under the microscope, Egyptian blue possesses large grains of an intense blue colour. Crystals are never visible. When grains are ground for use, the particles show irregular angular shapes. This pigment cannot be dissolved in the acids which are usually used for micro-chemical reactions. This feature differs from azurite, which can be dissolved in the same acids. The identification of three main elements, copper, calcium and silicate is enough to point to the existence of Egyptian blue. ${ }^{17}$ Egyptian blue can be identified through chemical analysis or the spectrometric analytical method. The painters of Egypt, Mesopotamia and Persia and later Greece and Rome, used Egyptian blue, while cobalt was used for painting glass smalt (Riederer 1997: 23-45).

\section{Smalt}

Cobalt ores were used for painting glass in Egypt and Persia and in the classical period. Production of the pigment: cobalt ore is baked to-

17 http://hr.scribd.com/doc/94722977/Egipatsko-plava gether with quartz and potash, sometimes melted glass is added. When it is poured into cold water, the blue falls apart into small pieces. After that, it is ground and floated. It has to be roughly ground in order to be used as a pigment. It was very rarely used in the paintings of ancient times and it grows in importance only from the Middle Ages onwards (Berke 2007: 21).

\section{Lapis Lazuli or natural ultramarine}

Ultramarine is a natural mineral pigment of the semi-precious stone Lapis Lazuli. This pigment is also called natural ultramarine. The name ultramarine derives from azzuro oltramarino blue from across the sea. ${ }^{18}$

In ancient times, Lazulite was much admired because of its stability and gloss, which depended on its purity. The stone was extracted with great difficulty, because by washing with water, it gets a grey tone. It is a durable and non-toxic pigment, resistant to light and alkali (Turinski 1990: 33). Due to its preciousness, it was applied onto already painted surfaces (Kraigher-Hozo 1991: 319).

In ancient times, it was mined only in Afghanistan (Turinski 1990: 33). The use of Lapis Lazuli was highly developed in Persian, Mesopotamian and Egyptian cultures (Berke 2009: 16).

\section{Indigo}

Indigo is an organic pigment known from the ancient times and obtained from the so-called indigo plants Indigofera Tinktoria. The colour is obtained when leaves of this plant are cut, bound into large bundles and put into pits. After that, they are placed in water with lime or some other alkali and left to ferment. In such a way, indigo white is obtained, which turns into indigo blue as a result of oxidation (Kraigher-Hozo 1991: 319).

Pliny mentions indigo as a product from India, describing it as sludge around a reed, which

18 http://www.handprint.com/HP/WCL/pigmtla. html\#lapislazuli 


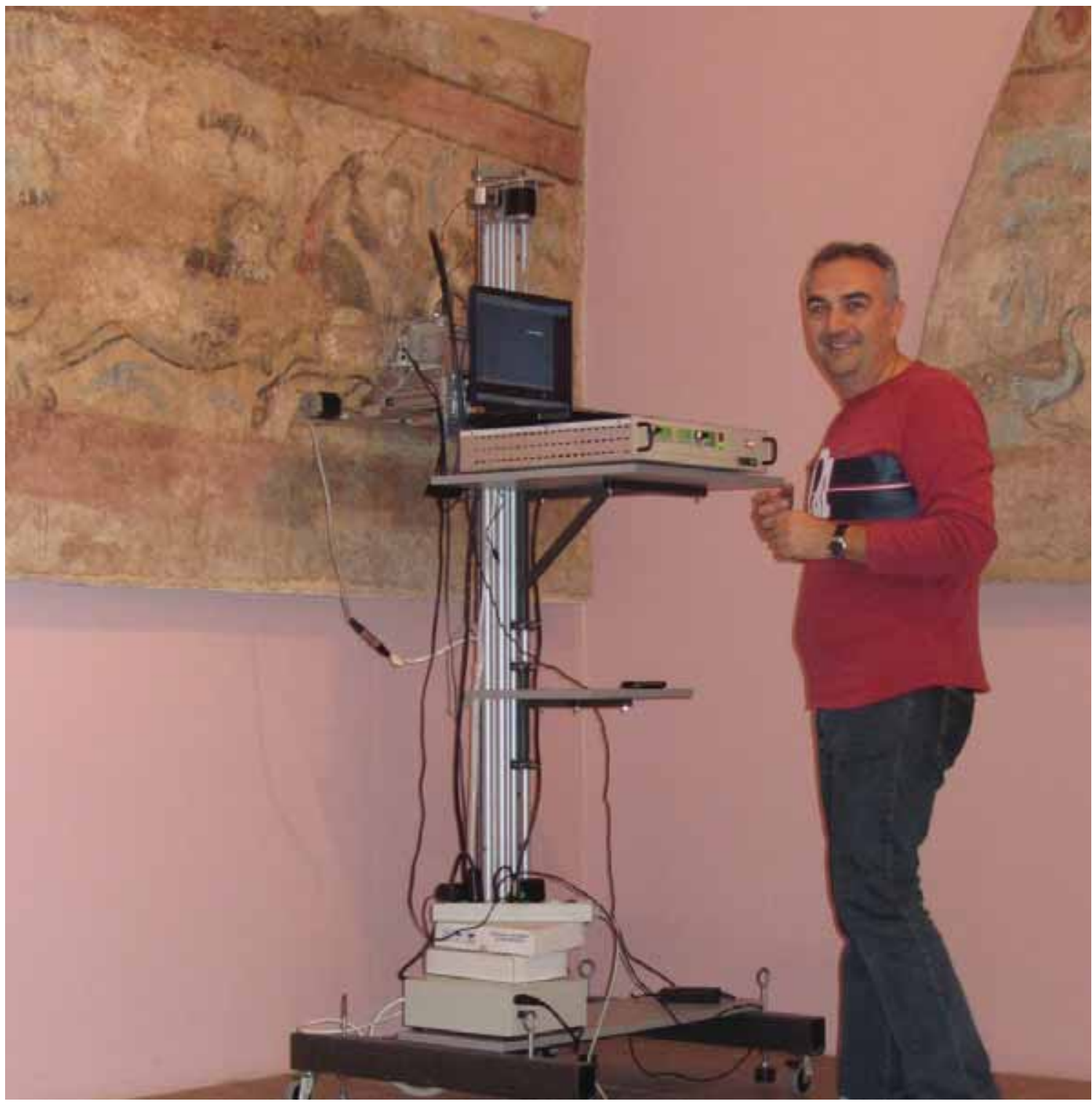

Fig. 5. The analysis of frescos at the National museum in Požarevac.

possesses a black colour after drying and sieving. After dilution it produces a mixture of purple and blue. Another kind is the so-called "scum of purple". Indigo forgers put pigeon faeces or earth from Sicily (white earth) in it. Pliny states that indigo is tested by annealing, resulting in pure purple. If it possesses a sea smell, it is considered to be collected around coastal rocks. The price of indigo is 20 dinars per pound. It was also used in medicine, for drying ulcers and the reduction of spasms (Pliny, XXXV. XXVII).

\section{ANALYSIS OF BLUE AND GREEN PIGMENTS ON FRESCOES FROM VIMINACIUM TOMBS}

\section{Analytical technique}

The analysis of pigments was performed in order to determine their elemental composition, by applying non-destructive EDXRF spectrometry (Fig. 5). The method applied was successfully used for the analysis of wall paintings and it has been established that it represents a valid 


\begin{tabular}{|c|c|c|c|}
\hline Tomb & Fresco & $\begin{array}{c}\text { Measuring } \\
\text { point }\end{array}$ & Colour \\
\hline \multirow{5}{*}{$\frac{n}{n}$} & \multirow{4}{*}{1} & $1-2$ & Bluish-green \\
\hline & & $1-3$ & Dark bluish-green \\
\hline & & $1-5$ & Dark \\
\hline & & $1-8$ & Blue \\
\hline & 2 & $2-7$ & Blue \\
\hline \multirow{3}{*}{ 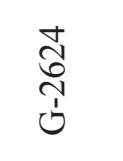 } & 3 & $3-2$ & Blue \\
\hline & \multirow{2}{*}{4} & $4-6$ & Light blue \\
\hline & & $4-7$ & Dark blue \\
\hline \multirow{5}{*}{$\begin{array}{l}\text { J } \\
\text { 号 } \\
\dot{1}\end{array}$} & \multirow{3}{*}{5} & $5-3$ & Blue \\
\hline & & $5-7$ & Blue \\
\hline & & $5-8$ & Blue \\
\hline & \multirow{2}{*}{6} & $6-5$ & Dark blue \\
\hline & & $6-8$ & Light blue \\
\hline \multirow{3}{*}{ 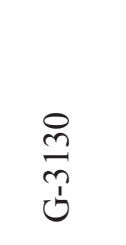 } & \multirow[t]{2}{*}{8} & $8-3$ & Green \\
\hline & & $9-2$ & Green \\
\hline & 9 & $9-3$ & Green \\
\hline
\end{tabular}

Table 2. Picture of measuring points and corresponding colours.

analytical method for characterising pigments in wall paintings (Akyuz 2009, Hradil 2008, Marey Mahmoud 2011). Information about the content of certain chemical elements makes it possible to not only conclude which pigments were used but also how they were used.

The portable EDXRF spectrometer, inhouse developed at the Vinča Institute of Nuclear sciences in Belgrade (Gajić-Kvaščev, 2012), consists of an air cooled X-ray tube (Oxford Instruments, Rh-anode, max $50 \mathrm{kV}, 1 \mathrm{~mA}$ ) with a pin-hole collimator and a SiPIN X-ray detector (6 $\mathrm{mm}^{2} / 500 \mu \mathrm{m}$, Be window $0.5 \mathrm{mil} / 12.5 \mu \mathrm{m}$ thickness and 1.5 inch detector extension), associated with a DSP (X123, Amptek Inc.) for spectra acquisition. Two laser pointers were used for the proper positioning and visualisation of the measuring spot in the cross-point of the exciting X-ray beam and detector axis, respectively. No filter and $40 \mathrm{kV}$ of high voltage, $800 \mu \mathrm{A}$ and a 100 s measuring time were selected as experimental parameters, and were kept constant during all measurements. Also, the distance between the sample and the $\mathrm{x}$-ray tube was $21 \mathrm{~mm}$, between the sample and the detector, $22 \mathrm{~mm}$, while the angle between the detector and the x-ray tube was $45^{\circ}$. The ADMCA (Amptek Inc.) software was used for spectra processing.

\section{Tomb G-5517}

Frescos from the tomb G-5517 were analysed at the National museum in Požarevac. Due to 




Fig. 6. Compared EDXRF spectra of green parts on frescos from the tomb G-5517.

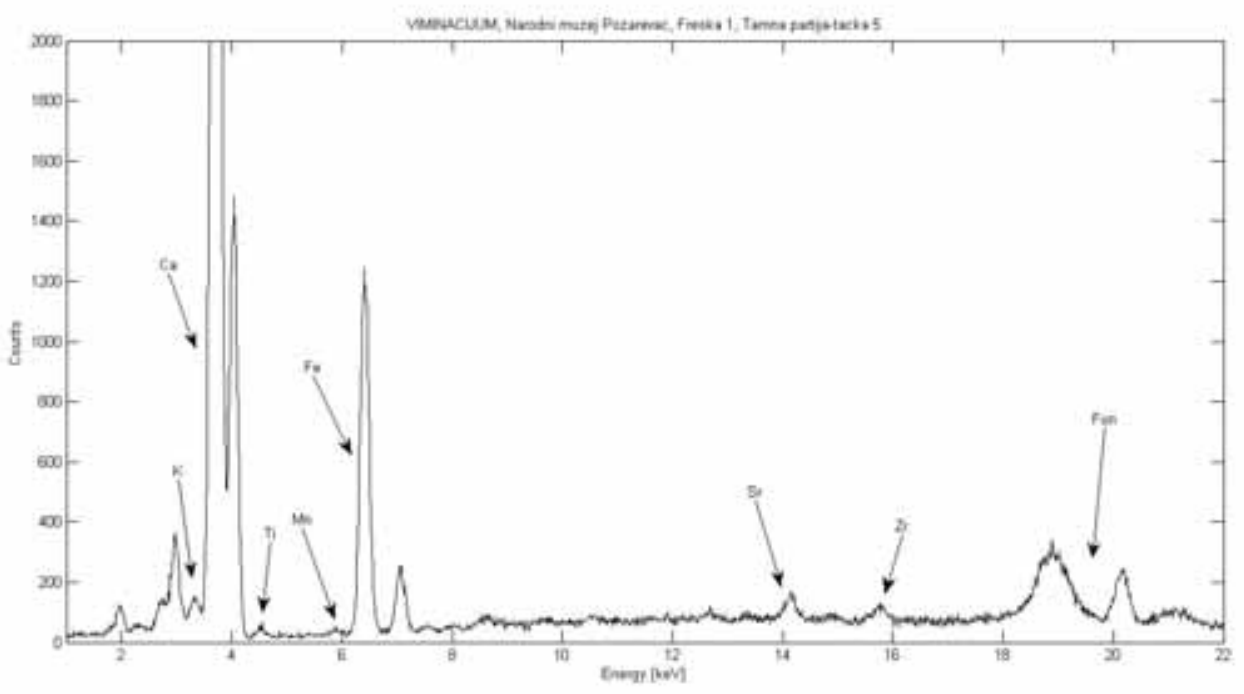

Fig. 7. EDXRF spectra of black earth.

specific conditions, not all of the frescos were accessible for analysis. Owing to the same reasons, it was not possible to perform analyses on all the parts of the painted layer. Two frescos from the tomb G-5517 were analysed, which were painted on the lateral sides (Fig. 1). An overview of the measuring points with corresponding colours is shown in table 2.

On these frescos, only two green parts of lighter and darker tone were analysed. Compared
EDXRF spectra of these analyses are shown on Fig. 6. According to these spectra, we can conclude the following. The presence of an intense copper peak $(\mathrm{Cu})$ within the spectrum indicates the usage of a green pigment based on this element, i.e. malachite, verdigris or chrysocolla. The limitations of the applied analytical method used for the identification of the elemental content do not make it possible to distinguish between these three pigments. The research performed so far 


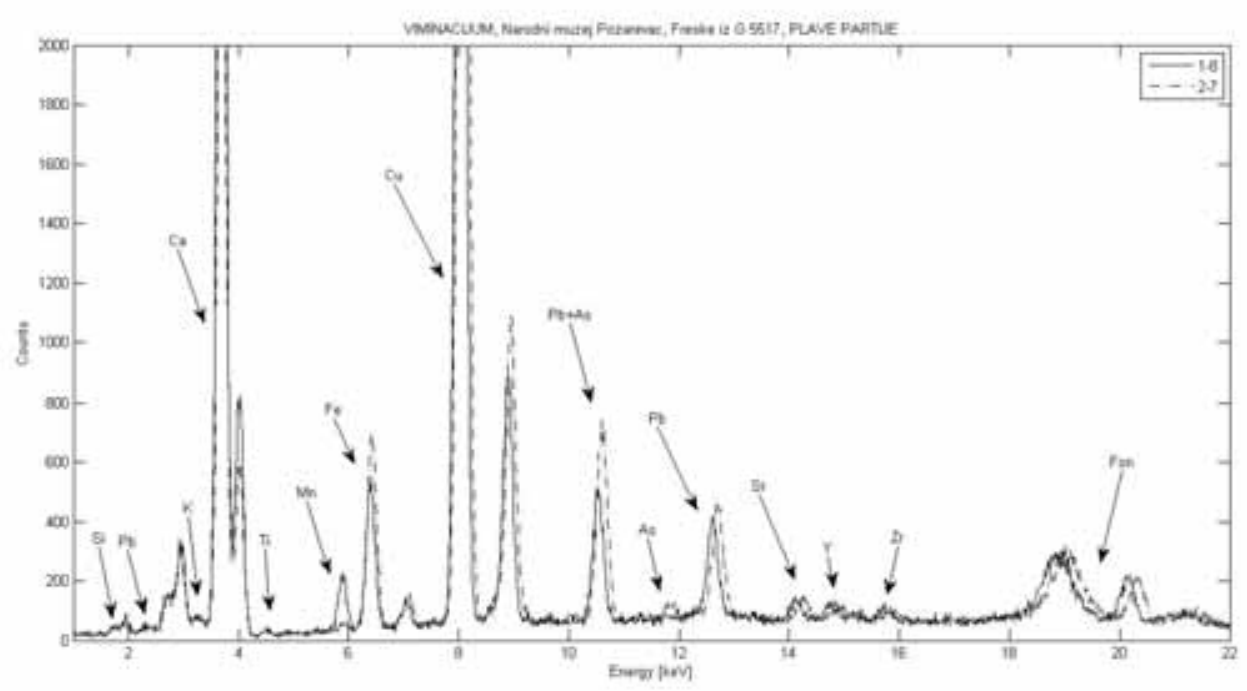

Fig. 8. Compared EDXRF spectra of blue parts of frescos from the tomb G-5517.

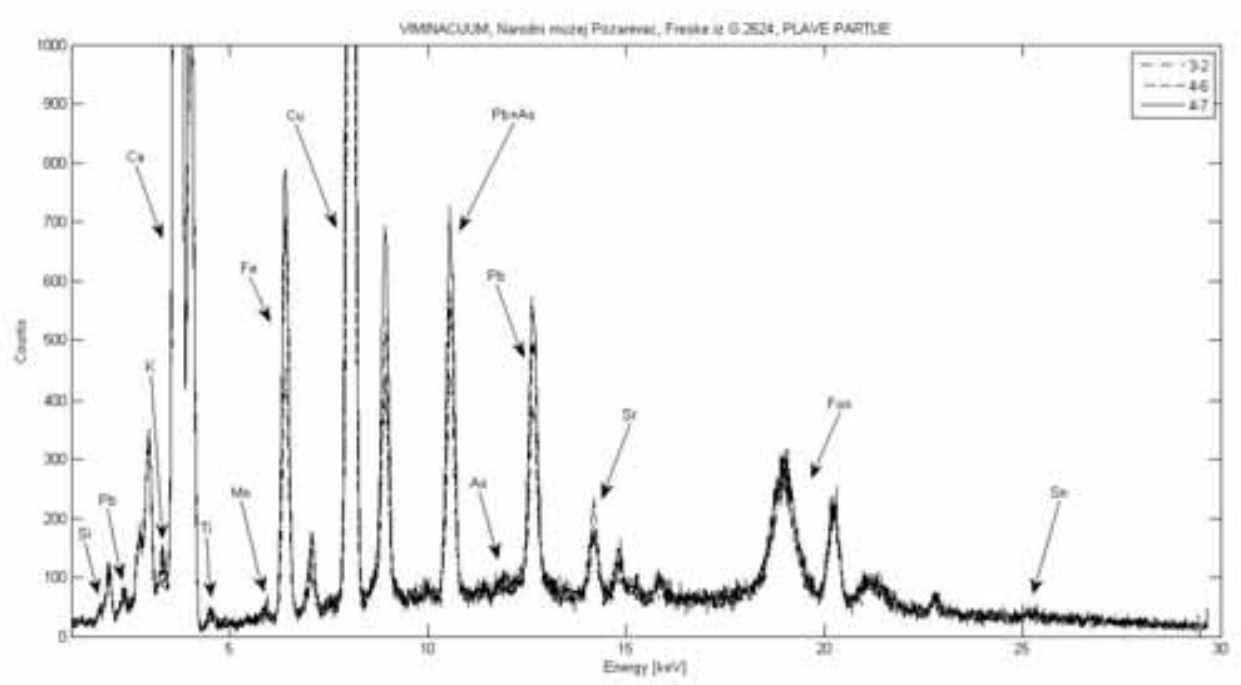

Fig. 9. Compared EDXRF spectra of blue parts painted using Egyptian blue and azurite.

(Gil 2008, Bevilacqua 2010: 185, 241) showed that a more precise identification according to the EDXRF spectrum can be obtained based on the presence of elements in traces. It is known that impurities which can appear in EDXRF spectra of malachite include $\mathrm{Zn}$, As and $\mathrm{Sb}$, although $\mathrm{Zn}$ is marked as an ever-present indicator of malachite. According to the intensity of the calcium (Ca) peak, which is almost the same for both nuances of green (Fig. 6), we can conclude that a mix- ture of pigments was used to obtain the desired nuance. In this sense, we can say that the darker tone of green was obtained by mixing a copper pigment with some kind of dark earth. An indicator for black earth is an intense peak of iron $(\mathrm{Fe})$ within the spectrum of point 3 (Fig. 6), as well as peaks of potassium (K), titanium (Ti) and manganese $(\mathrm{Mn})$, which show the presence of these elements in traces. Confirmation of this is also obtained from the spectrum shown in Fig. 7. A small 


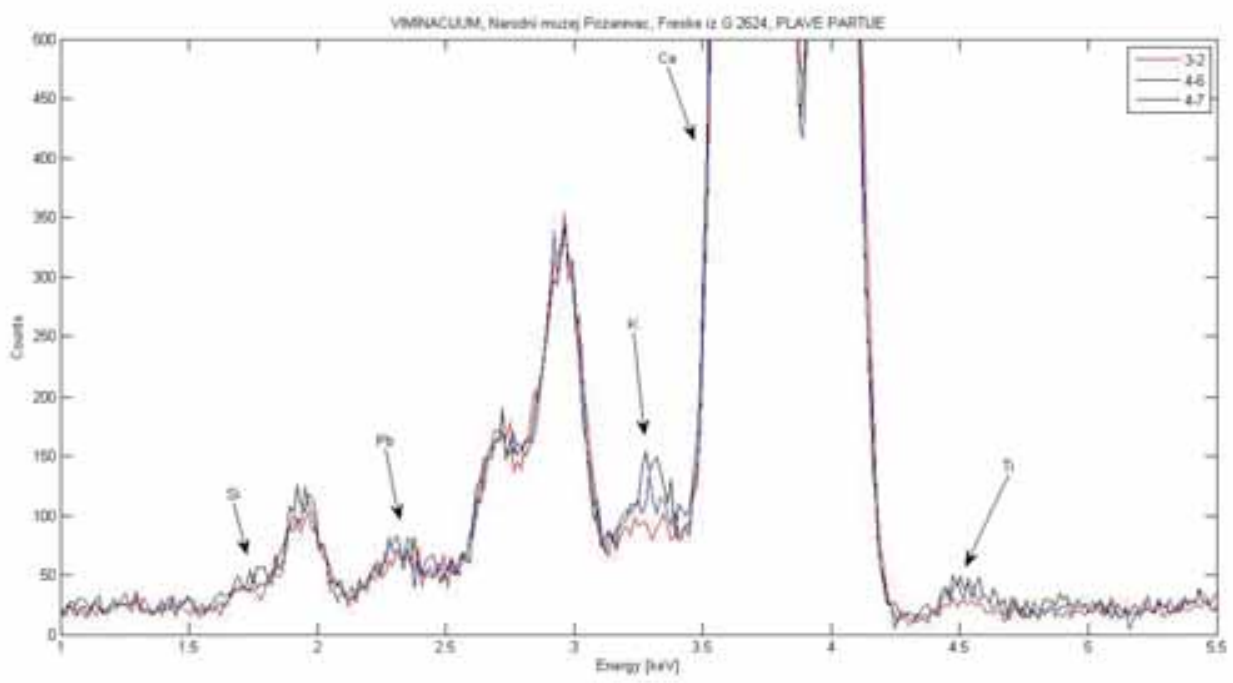

Fig. 10. Detail from the spectra in Fig. 9.

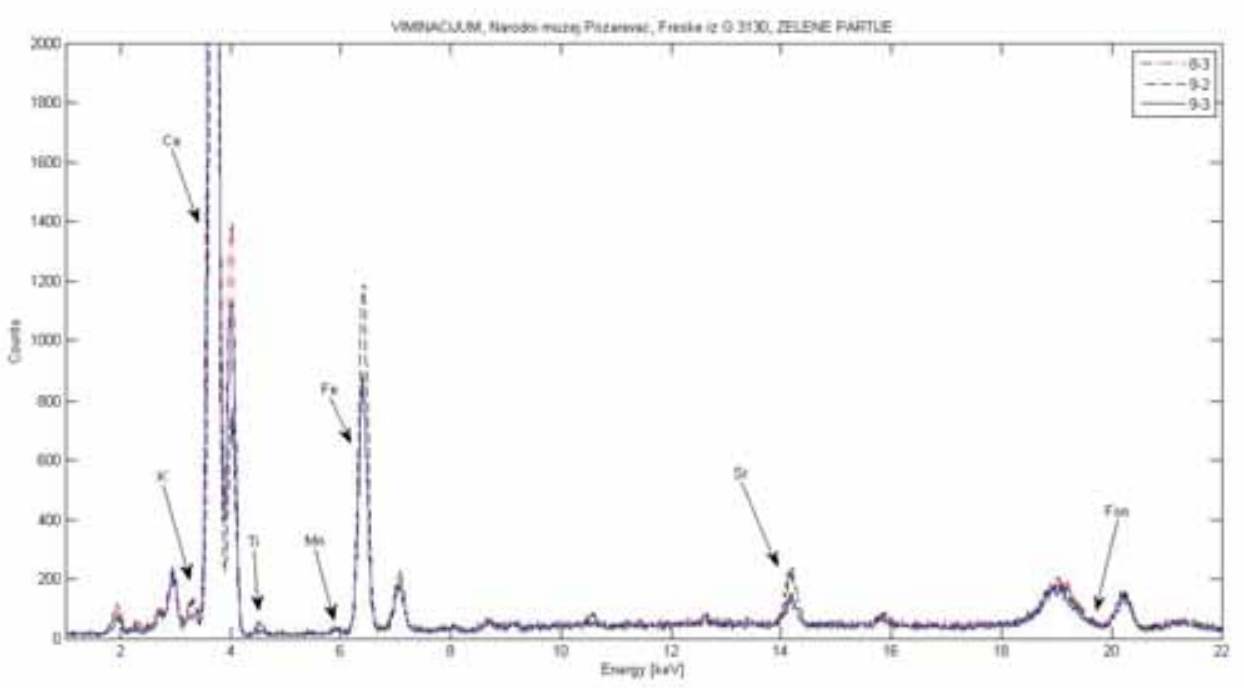

Fig. 11. Compared EDXRF spectra of green parts painted using green earth.

trace of mercury $(\mathrm{Hg})$ indicates more impurities and less use of vermilion to obtain the desired nuance. A slightly higher peak of lead $(\mathrm{Pb})$ within the spectrum of the lighter tone indicates a small admixture of lead white for lightening the copper green pigment.

Blue parts on the frescos from the tomb G-5517 were analysed at two points. Compared spectra for these two points are shown in Fig. 8. A very intense peak of copper $(\mathrm{Cu})$ indicates that, for these parts, either Egyptian blue or azurite was used. A more precise identification of these two pigments can be obtained according to impurities which can be detected with the method applied (Bevilacqua 2010: 185). In this way, the presence of Si and As in these spectra shows that, for these parts, Egyptian blue was used. Unlike the green parts, in which it is suspected that there was the use of a mixture of pigments applied in one layer, here a multi-layering of the analysed painted points can be supposed. This conclusion is derived from the intense peak of manganese (Mn), 


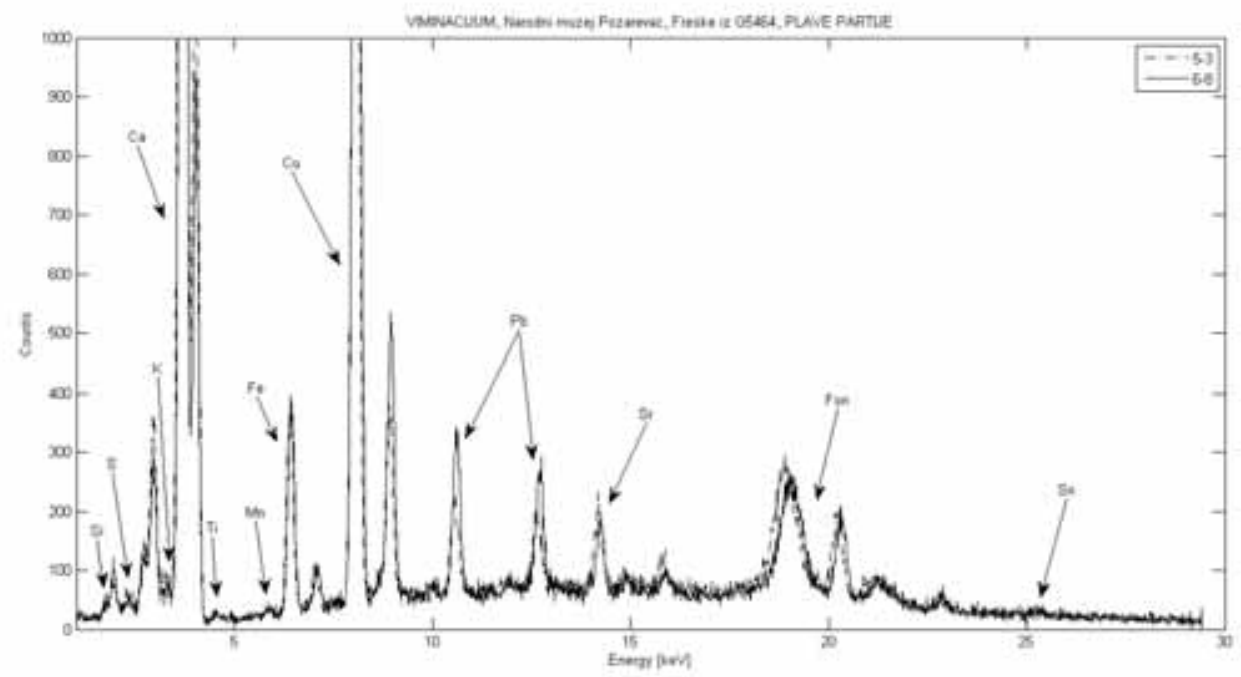

Fig. 12. EDXRF spectra of blue parts painted using Egyptian blue pigment.

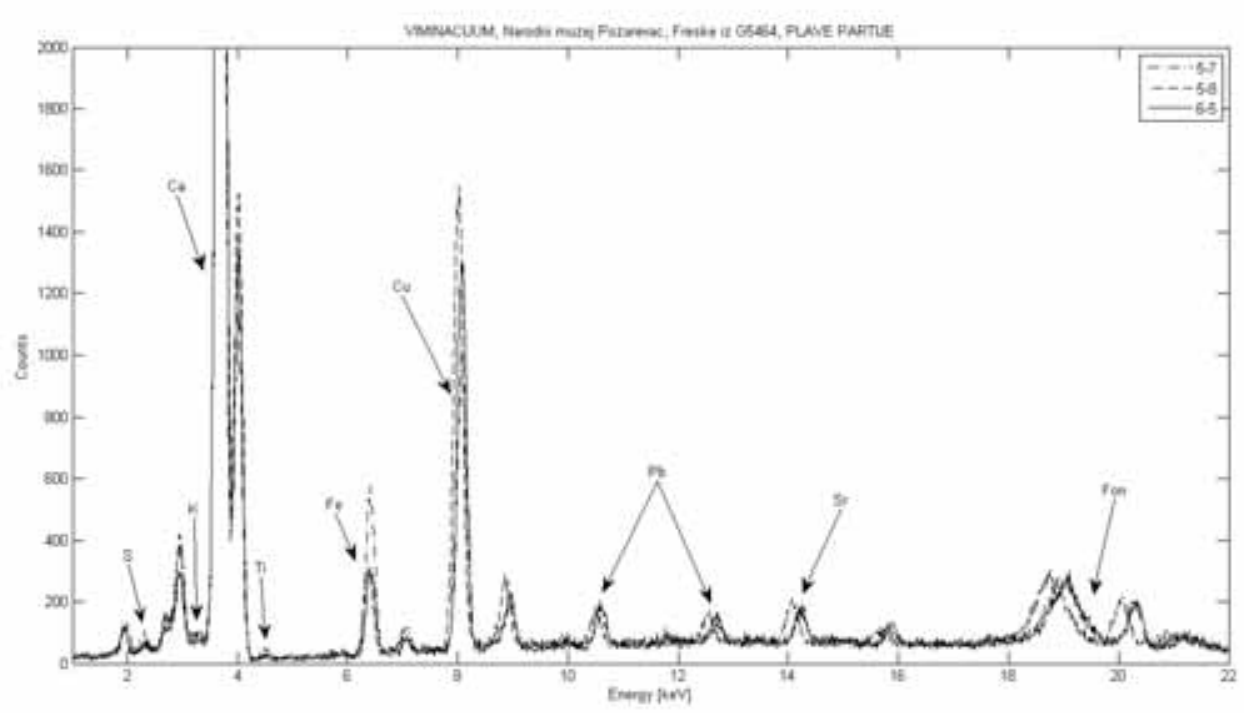

Fig. 13. EDXRF spectra of blue parts painted using azurite.

as well as from different intensities of the peaks of calcium $(\mathrm{Ca})$ and iron $(\mathrm{Fe})$ for the same nuances of the basic pigment.

\section{Tomb G-2624}

The frescos from the tomb G-2624 were analysed at the National museum in Požarevac. An overview of the analysed points with the corresponding colours is shown in table 2. Blue parts of these frescos were analysed at three points. Compared EDXRF spectra of these analyses are shown in Fig. 9.

A detail from Fig. 9 is shown in Fig. 10. According to these graphs, one can conclude that, apart from the precious Egyptian blue, azurite was also used for painting blue parts.

\section{Tomb G-3130}

Frescos from the tomb G-3130 were analysed at the Domus Scientiarium in Kostolac (Viminacium). An overview of the analysed points with the corresponding colours is shown in 
table 2. The green parts in these frescos were analysed at three points. Compared EDXRF spectra of these analyses are shown in Fig. 11. According to these spectra it can be concluded that for the painting of the green parts of these frescos, green earth was used.

\section{Tomb G-5464}

Frescos from the tomb G-5464 were analysed at the Domus Scientiarium in Kostolac (Viminacium). An overview on the analysed points with the corresponding colours is shown in table 2. The blue parts on these frescos were analysed at five points. Compared EDXRF spectra of these analyses are shown in Fig. 12 and 13. According to these spectra we can conclude that, apart from Egyptian blue, azurite was also used.

\section{CONCLUSION}

In this paper, only pigments which were used during Antiquity are discussed. This study includes experimental work on specific examples of late antique tomb paintings from Viminacium. Since all of these wall paintings belong to the same period ( $4^{\text {th }}$ century), compared results obtained are of great importance. The current knowledge of pigments used during antiquity and late antiquity in Serbia is not based on specific examples, but on examples from literature and written sources. Here, complete analytical data are obtained about the pigments used in late antiquity, since analyses derive from a huge sample. These results will be compared with future results of pigments from other Viminacium objects.

The identification results of the pigments used for the wall paintings using the non-destructive EDXRF spectrometry method shows that this analytical method can successfully be used for this purpose. Limited accessibility to the frescos during this procedure, as well as the reduced number of well preserved painted parts for this kind of analysis, made it impossible to perform research on a larger scale or to draw more precise conclusions. Even so, the work of teams of experts from the natural sciences and humanities made it possible to overcome these limits.

Green pigments - On tomb frescos from Viminacium, green parts were analysed on three frescos. According to these analyses, it can be said with a degree of certainty that, for the wall paintings of tomb G-5517, some of the copper based green pigments were used: malachite, verdigris or chrysocolla. The applied analytic method is limited to the analysis of the composition of the elements, while the more precise analysis distinguishing between the three pigments is performed indirectly, i.e. according to the elements in traces. In this case, owing to the presence of zinc ( $\mathrm{Zn})$ in traces, we can presume that malachite was used ( $\mathrm{Zn}$ is an ever present indicator of malachite). To obtain darker tones, malachite was mixed with black earth. Data can be found in literature regarding the mixing of Egyptian blue or azurite with yellow ochre to obtain desirable tones of green. However, these analyses did not confirm this approach (no typical elements of yellow ochre such as titanium-Ti or manganese-Mn, were detected).

Apart from copper based green pigments, the analyses confirmed that green earth was used on frescos from the later period. Through these analyses, no use of both kinds of pigments was confirmed in frescos from one single tomb, but it can not be stated for sure, because of low availability of suitable measuring points

The use of the aforementioned copper based green pigments was well known and widespread during the period in which the frescos were painted. Indirect analysis based on the detected elements in traces can be of further help in the detection of the pigment used. The precise identification of the copper based pigment used is not possible with the method applied. The precise identification requires either the application of some other non-destructive method (for which 
there were no technical conditions) or the collection of samples for a detailed chemical analysis.

Blue pigments - Within the spectra of blue parts from the Viminacium tomb paintings, copper is the most abundant chemical element, providing important information about the pigment used. According to this, as well as to the analyses of elements in traces which indicate certain pigments, it was concluded that Egyptian blue and azurite were used most probably. On frescos from the tomb G 5464 both pigments were used, which corresponds to the data found in literature regarding the addition of small amounts of the more precious Egyptian blue to the more affordable azurite (Siddall 2006).

\section{BIBLIOGRAPHY}

Agraval, O. P., Pathak, R. 2001

Examination and Conservation of Wall Paintings a Manual, Sudeep Prakashan, New Delhi.

Akyuz, S., Akyuz, T., Basaran, S., Kocabas, I., Gulec, A., Cesmeli, H. and Ucar B. 2009

FT-IR and EDXRF analysis of wall paintings of ancient Ainos Hagia Sophia Church. Journal of Molecular Structure, Vol. 924-926, 2009, 400403.

\section{Antonović, D., Vukadinović, M. 2012}

Eneolithic mine Prljuša- Mali Šturac, Archaeological and geophysical investigations, , Starinar LXII/2012, 95-105.

\section{Berke, H. 2009}

The invetion of blue and purple pigments $i$ ancient times, Chemical Society Reviews, 36, 15-30.

Bevilacqua, N., Borgioli, L, Adrover Gracia, I. 2010,

I pigmenti nell'arte dalla preistoria alla rivoluzione industriale, Collana i Talenti, il prato, Saonara, Italy.

\section{Brkić, N. 1991}

Tehnologija slikarstva, vajarstva i ikonografija, Beograd.

Gajić-Kvaščev M., Marić Stojanović M., Šmit Ž., Kantarelou V., Germanos Karydas A., Šljivar D., Milovanović D. and Andrić V. 2012, New evidence for the use of cinnabar as a colouring pigment in the Vinča culture. Journal of Archaeological Science, 39, 4, 2012, 1025-1033.

Gil, M., Carvalho, M. L., Seruya, A., Ribeiro, I., Alves, P., Guilherme, A., Cavaco, A., Mira o, J. and Candeias, A. 2008,

Pigment characterization and state of conservation of an 18th century fresco in the Convent of $\mathrm{S}$. Anto' nio dos Capuchos (Estremoz). X-Ray Spectrom. 2008; 37: 328-337.

Hradil, D., Hradilová, J., Švarcová, S. and Kotulanová E. 2008,

Hand-Held XRF for the Preliminary Screening of Early Romanesque Frescoes in Slovakia, 9th International Conference on NDT of Art, Jerusalem Israel, 25-30 May 2008.

Kajtez, S. 2011

Slikarske tehnike, Beograd, izdavač.

Korać, M. 2007

Slikarstvo Viminacijuma, Centar za nove tehnologije - Viminacijum, Beograd

\section{Krajger-Hozo M. 1991}

Slikarstvo/metode slikanja/materijali, Svijetlost, Sarajevo.

Körlin, G. 2010

Luxusgut Blau - Römischer Azuritbergbau in Wallerfangen/Saar, Der Anschnit 62, H.4, 174-189.

Marey Mahmoud H., Kantiranis, N. Ali, M. and Stratis J. 2011, 
Characterization of Ancient Egyptian Wall Paintings, the Exavations of Cairo University at Saquara. International Journal of Conservation Science Vol. 2, Iss. 3, 2011, 145-154.

Mattei, E., De Vivo, G., De Santis, A., Gaetani, C., Pelosi, C., Santamaria, U. 2008

Raman Specroscopic analysis of azurite blackening, Journal of Raman Specroscopy, 302-306.

\section{Mazocchin, G.A., Rudello, D., Bragato, C., Ag-} noli, F., 2004

A short note on Egiptian blue, Journal of Cultural Heritage 5, , 129-133.

\section{Медић, М. 1999}

Стари сликарски приручници, Ираклије, Х век, Теофил Презвитер, ХІІ век, Ченино Ченини, $X I V$ век, Милорад, Београд.

Рогић, Д., Анђелковић, J.2011

Вегетабилни мотиви у касноантичком и ранохришћанском фунерарном сликарству на територији Србије, Ниш и Византија X, Prosveta (Niš), 2011, 85-104.

\section{Riederer, J. 1997}

Egyptian Blue, in Artists' Pigments: A Handbook of their History and Characteristics, ed. E. W. FitzHugh, Oxford University Press, Oxford, vol. 3, pp. 23-45.

Scott, D. 2002

Copper and Bronze in Art: Corrosion, Colorants, Conservation, Getty Trust Publications: Getty Conservation Institute, Los Angeles.

\section{Siddall, R. 2006}

"Not a day without a line drawn": Pigments and painting techniques of Roman Artists, Magazine infocus, The proceedings of the Royal Microscopical Society, 2, 18-31.
Turinski, Ž. 1990

Slikarska tehnologija, Beograd.

Pliny

Pliny, Natural History, Libri XII-XVI, with an English Translation by H. Rackham, London, 1968.

\section{Vitruvije}

Vitruvije, Vitruvijevih deset knjiga o arhitekturi, Sarajevo, 1951.

http://hr.scribd.com/doc/22149681/Pigmenti-uslikarstvu-Pigments-in-the-painting

\section{REZIME \\ ANALIZE PLAVIH I ZELENIH \\ PIGMENATA SA FRESKO \\ OSLIKANOG GROBA IZ VIMINACIJUMA}

\section{KLJUČNE REČI: EDXRF, PIGMENT, ZELENO, PLAVO, ZIDNO SLIKARSTVO, KASNA ANTIKA.}

Rad se bavi analizom plavih i zelenih pigmentata kasnoantičkih zidnih slika grobnica (G5517, G-2624, G-3130 i G-5464) iz Viminacijuma. Ove grobnice pronađene su prilikom arheoloških istraživanja u periodu od 1983 do 1990 godine.

Elementalni sastav pigmenata određivan nedestruktivnom EDXRF spektrometrijom. Na osnovu rezultata možemo reći da su zelene nijanse zidnih slika iz Viminacijuma uglavnom pigmenti na bazi bakra kao malahit, verdigris i hrizokola, mada je korišćen i zemljani pigment - zelena zemlja. Plavi pigmenti su na bazi bakra. $\mathrm{Na}$ osnovu analize elemenata u tragovima koji su pratioci pojedinih pigmenata zaključeno je da su korišćeni Egipatsko plava i azurit, kao i njihove kombinacije.

Do sada su primeri analiza pigmenata zidnog slikarstva antičkog i kasnoantičkog perioda u Srbiji navođeni na osnovu literature, nije poznato 
da su rađene analize na ovako velikom uzorku.

Dobijeni rezultati moći će da se porede sa budućim rezultatima analiza zidnog slikarstva istog perioda iz drugih objekata Viminacijuma, kao i sa drugih arheoloških nalazišta u Srbiji kojima će se dobiti potpunija saznanja o paleti kasnoantičkog perioda u Srbiji. 